\title{
Chinese Folk Photographic Creations of Western Photographers
}

\author{
Ting Zhou ${ }^{1}$ \\ ${ }^{1}$ Fine Art School, Nanjing Normal University, 1st Wen Yuan Road, Nanjing 210046, Jiangsu, China \\ Correspondence: Ting Zhou. E-mail: 13851830020@163.com \\ Received: March 20, 2017 \\ Accepted: May 26, 2017 Online Published: June 23, 2017 \\ doi:10.5539/ass.v13n7p190 \\ URL: https://doi.org/10.5539/ass.v13n7p190
}

\begin{abstract}
Folk cultures contribute to the important composition of the traditional culture in China, a multiracial ancient civilization enjoying a profound history. Folk photography opens a window for the world to enable people in other countries to understand China as well as its traditional culture. Western photographers have created a large amount of folk photographs during over a century of corresponding development. These works mean not only great significances to the documentation and heritage of Chinese folk cultures but also enormous contributions to the communication of Chinese folk cultures towards the global community. The paper reviewed the Chinese folk photographic creations of western photographers from mid-19th century to early 21 st century, and discussed the connotations and meanings of these works.
\end{abstract}

Keywords: Chinese folklore photography, Western Photographers, Folk cultures

\section{Introduction}

As an important composition of the traditional culture of one nation, folk cultures profoundly illustrate the history and culture of the nation. Folk photography is a new photographic category (Sun, 2014) concerning the folklore researches and photographic art displays. Focusing on the folk items, such photographic activities provide great realistic significances to the rescuing and protection of folk cultures. Folk photographs can be created on all-embracing materials, including characters and clothes, residential architectures, life etiquettes, religious rites, etc. Photographic documents are more specific and direct than the text form, which is particularly significant in the protection and communication of intangible cultural heritages (Tao, 2012).

China is a worldly ancient civilization consisting of 56 nations, making the folk cultures of nations the important part of the Chinese culture and the shared spiritual fortune of the Chinese nation (Tan, 2004). A variety of distinctive and colorful national cultures have emerged in the 5000 years old history of Chinese nation. Over the more-than-100 years from mid-19th to early 21 st century, massive western photographers embarked on Chinese lands to create a great amount of folk photographic works. They have expressed the attention towards the Chinese folk customs, which are traditional, nation-oriented and regional, and the passion towards Chinese traditional culture through the artistic approach of folk photography (Qi, 2005).

\section{The Infancy Stage}

Chinese folk photography sprouted in the 19th century when westerners carried photographic equipment to take portraits as early as the end of the First Opium War. They brought home a lot of scenic and architectural photos taken in the South China. Foreign photographers were allowed to take pictures in a limited territory of China before the 1870s. Restrictions were set on, besides of the range of motion, the types of photographs to a great extent, namely only pictures of ancient architectures and characters were permitted for foreign photographers. After the Second Opium War, China alleviated such restrictions. Western photographers were able to travel around China to take photos in their favorite way. Many photographers transmitted their focuses from scenes and architectures to the folk customs. Their best representations include American photographers Reverend Justus Doolittle and Luther Knight, British photographer John Thompson, and French photographer Albert Kahn.

Reverend Justus Doolittle, the American missionary who was fulfilling his works in the Southeast China during the mid-19th century, published his 1968 collection Social Life of the Chinese to document Chinese etiquettes and religious cultures of that time. In 1868, British photographer John Thompson set out a journey from HK to China mainland via Guangzhou, Shantou, Xiamen, Shanghai, Ningbo, Beijing and the Central Plains of Middle China. He created and released photo collections including Illustrations of China and Its People. These photographs delivered the living conditions and national customs of Chinese people to the entire world. 
Folk-custom photographs account for a large proportion in his works. Covering a wide range of subjects, he had various humanity and social pictures of the late Qing Dynasty, including the local customs of nations, ancient architectures, religious cultures and production activities, recorded in large format, e.g. "The Manchu Bride in Beijing" (Figure 1) and "The Peddler Selling Fruits" (Figure 2).

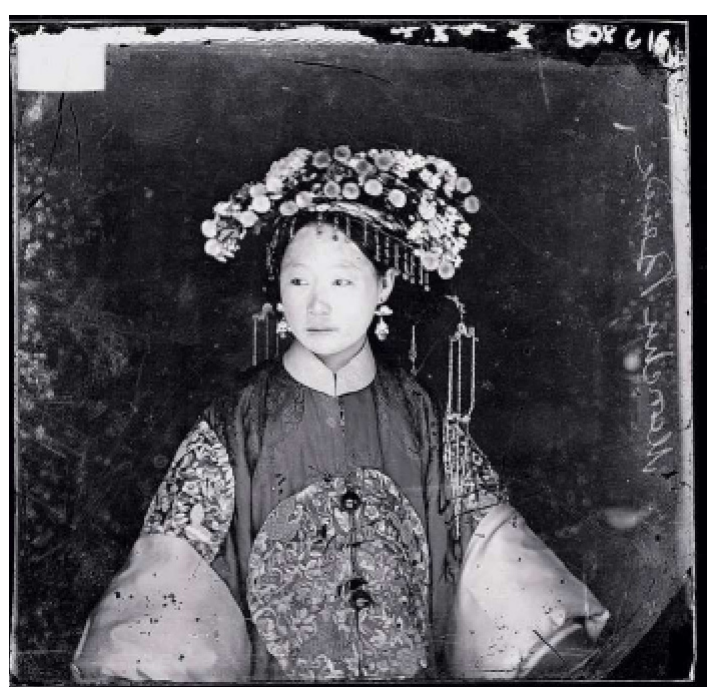

Figure 1: The Manchu Bride in Beijing (Gen 2011)

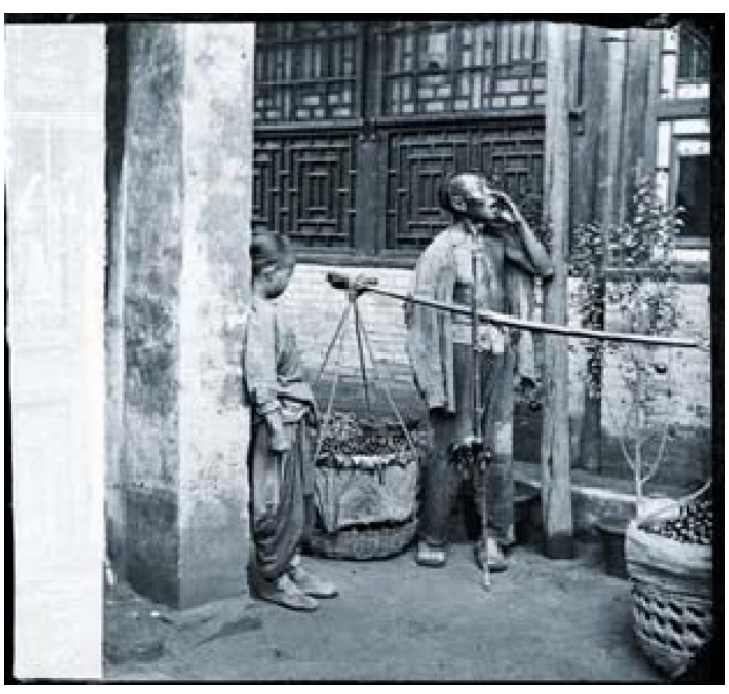

Figure 2: The Peddler Selling Fruits(Gen 2011)

American teacher Luther Knight took plenty of realistic photos on his faculty in Sichuan during the early 20th century, documenting the social environment when living and working in Sichuan and the folk customs where he traveled, which involved precious details regarding lives, farm works, businesses and trades, etc. Back then, Chinese society was in transformation. After the invasion of western powers following the Opium War, various sectors of modern China society under the governance of Qing Dynasty went through drastic changes and reforms, which resulted in the transformation of all sectors including the modern folk customs in China. It was in above historical background that Luther Knight stepped onto the tough yet noble path of examining the Sichuan national cultures. Knight recorded the folk customs of Sichuan from multiple perspectives including the lives, farm works, businesses and trades, etc. Among his photos, there were "Qingyang Temple Fair" that revealed the living folk, and the "Ox Sacrifice in the Beginning of Spring" that revealed the farm work folk. His works offer not only the experiences of the epoch development and historical reforms, but also the understanding towards many folk customs with local characteristics. These images are, in addition to the demonstration and description of historical customs in Sichuan between the late Qing Dynasty and early Republic of China, one evidence for the development of Chinese modern photography (Zhou, 2016).

In 1909, French photographer Albert Kahn began his once-in-a-lifetime Chinese visit from Shanghai, during which he successively travelled by Qingdao, Tianjin, Beijing, Hankou, Nanjing and other cities and finally ended the visit with the voyage from Shanghai to HK. Hundreds of color photographs were taken in four regions of China by Mr. Albert Kahn and his photography team, consisting of the earliest color photographs about China discovered until now. These aged photographs, despite of their long histories, remain breathtaking and provide the touchable images of China in the early 20th century. The ancient Beijing courtyard houses, Confucian Temple, stores, weddings, street scenes, city gates and other subjects in his photographs have reproduced Chinese local customs and architectures of a century ago.

In 1927, China and Sweden jointly organized "The Sino-Swedish Scientific Expedition to the North-Western Provinces of China", which was the first large-scale expedition jointly founded by China and foreign scholars. Researchers applied cameras to document the special geographic environment, ancient city ruins and local folk customs in the Northwest China during the examination. These precious photographs about the living conditions of minor nations have recalled our attention on the western territory.

\section{The Steady Growths}

The decades between 1930 and 1950 are called the golden age of news photography, during which important magazines and weekly publications gained a large population of readers by photographic works. The Magnum 
Photos was started in 1947 by Henri Cartier Bresson and Robert Capa, both of whom were important western photographers focusing on Chinese cultures. Cartier Bresson arrived in China in 1948 to take photographs and formulate reports about the country of that time. His one-year residence in China included six months before the collapse of the Kuomintang and six months after the birth of New China. The pictures he captured became valuable historical materials for keeping authentic records of the great transformation in Chinese history. Besides of the historical reforms, they also obtained plenty of photos regarding the establishment of China and the lives of people, exerting influences on generations of Chinese photographers. Figure 3 shows people practicing Taiji outside the Imperial Palace.

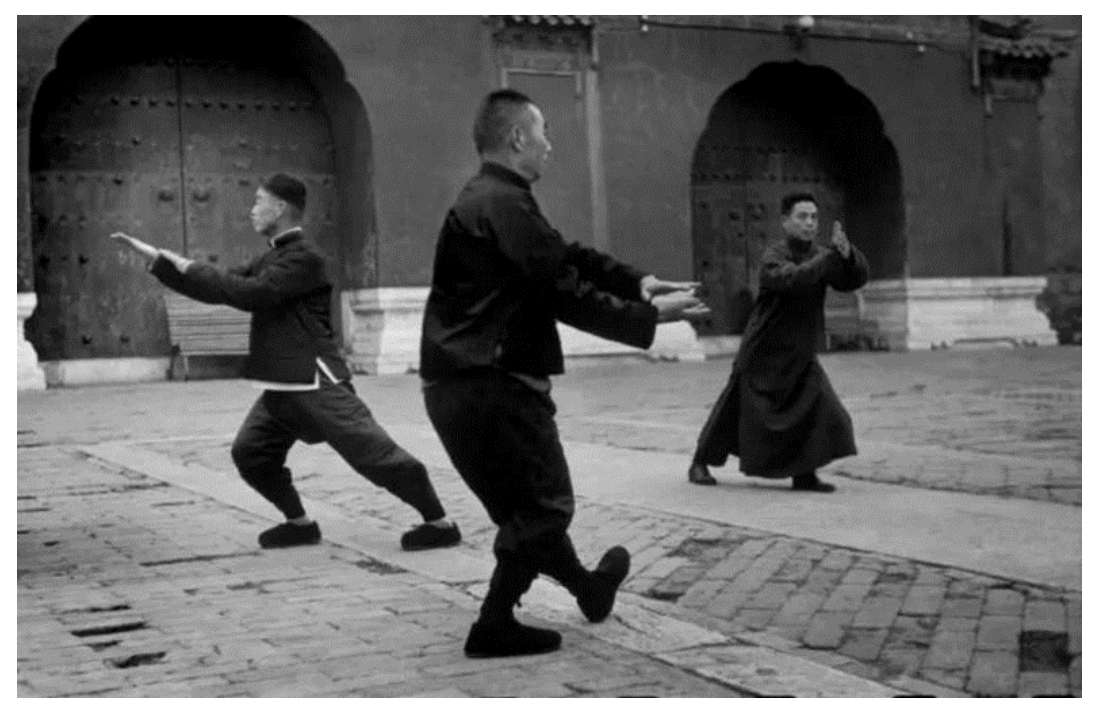

Figure 3. People Practicing Taiji outside the Imperial Palace (Gen 2011)

Due to various causes, only a limited number of foreign photographers were allowed into China apart from a few press-photographers of foreign news agencies or newspapers from 1948 to 1978. Marc Riboud was the first photographer having permission into China in the 1950 s, who later received repeated invitations from Premier Zhou Enlai to visit our country. Over half a century ago, Marc Riboud departed from India for Guangzhou via HK, and travelled up north to capture Chinese sights along the journey, which included his experiences in Wuhan and the Yangtze River Bridge in construction. The multiple photos taken by the famous French photographers have become historical documents of the great changes in China. Marc Riboud visited China for over 20 times since 1957 to witness and record certain historical events. According to his statement, he has wondered on the Beijing Wangfujing Street at higher frequency than on the Avenue des Champs-Elysees. Marc Riboud has left many classical photos about Chinese daily lives, clothes, folk acrobatics, festival performances, etc. His publications include The Three Banners of China and Visions of China.

Along with the Reform and Opening-up, numerous foreign photographers have swarmed into China since 1978 (Yang \& Hu, 2015). They have been dazzled at all of the vast territory, profound history, splendid culture and rapid changes in China. As Stewart Franklin, the Director of Magnum Photos, once illustrated about the close relationship between Magnum and China in an interview: "Any photographer interested in recording histories will be attracted by China." French photographer Yann Layma visited China for multiple times since 1985, creating the precious wealth of color photos reflecting China during nearly 30 years. According to insiders, "Most of Chinese pictures published on the foreign newspapers and magazines during 1980s and 1990s were taken by Layma". The artist created over 60 photographic reports and five books about China in a continuous order. A large amount of folk elements were included into the works of Layma. He arrived in the remote valley in Sanjiang Dong Autonomous County in the early 1990s to take a huge batch of vivid photos about the folk customs of the Dong Nation (figure 4). In 2001, he carried out six months of photography at Wudang Mountain in spite of illness, documenting the architectures and history of the mountain. Yann Layma was awarded Legion of Honor in 2005 for his outstanding contributions to the Sino-French cultural exchanges. 


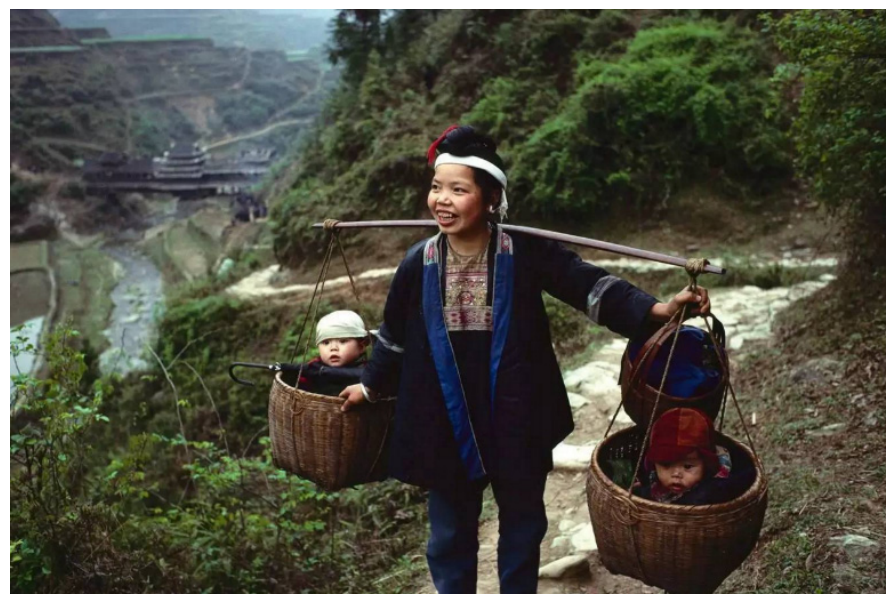

Figure 4. The Dong Woman Carrying Children (Gen 2011)

\section{The Rapid Development}

Photographer Shen Che founded the China Folk Photography Association as the Chairman in 1993. Since then, the term "Folk Photography" has gradually become the name of an independent area. In 1998, the association officially launched the first Humanity Photo Awards of International Folk Photography in China, which was a biennial global competition supported and authorized by the UNESCO with the right to use its logo. Folk photography began to enjoy an expanded concept and the stage of standardized operation and steady improvement when the cross-border communication and integration of Chinese folk cultures had been accelerated thanks to western photographers who were devoting themselves into Chinese folk photography (Yang, 2014). Their representations include Polish female photographer Wiktoria Stefania Wojcieachowska, German photographer Michael Wolf, Russian photographer Viktoriia Rogotneva, etc.

The cloths sector of 2015 Humanity Photo Awards was awarded to the People Wearing Raincoats in Hangzhou created by Polish photographer Wiktoria Stefania Wojcieachowska. The artist captured the rain scene consisting of the facial expressions of people, their different emotions towards the bad weather, the exhaustion, and colorful raincoats snatched by the wind. The photograph has exhibited a unique multi-cultural integration through the varied faces, emotions and physical languages of characters.

One set of pictures displaying the fishing cormorants in Guilin of China was published on the Daily Mail website of Britain in 2015. These photographs were taken by the Russian photographer Viktoriia Rogotneva on the Lijiang River of Guilin, Gunagxi in China. We are able to find the peaceful time outside the noisy world as well as the millennial tradition of the ancient watery region in these photos. Chinese fishermen have maintained a particular morning habit for thousands of years. They train the cormorants to catch fishes, which seize fishes from the depth of water and deliver them onto the crafts in obedience. It is a traditional fishing approach that causes no damage to the eco-environment at all. The pictures establish the harmonious and natural atmosphere with a cormorant, a gaslight, and a fishing net.

Thierry Bornier is a French professional photographer employed by National Geographic who is now living in Yunnan of China after seven years of working and living in New York. He has founded the project Lenscape China to focus on the attractive sights and folk customs in the West China. Thierry Bornier has set foot on various provinces, e.g. Yunnan, Sichuan, Hunan, Guangxi, Tibet, Inner Mongolia and Qinghai, and published several Chinese collections. His works include Fishing in Xiapu Bay, Early Morning Labor, etc.

\section{Significances of Creations from Western Photographers}

\subsection{Documenting Chinese Culture}

China is home to one of the world's greatest ancient civilizations. The national culture is an important part of Chinese culture and is shared by all Chinese people. In the long course of history, all Chinese ethnic groups have created a variety of distinctive and colorful ethnic cultures. Compared with written accounts, photographs seem more intuitive and specific in recording, collecting, organizing folklore cultures of all regions and ethnic groups (Jiang, 2008). After the extensive application of photographic techniques in the west world, many western photographers started to explore new grounds for photographic creations. Meanwhile, China remained a closed society of secret social formation and living conditions in the views of foreigners, which invited great curiosity 
in European towards the mysterious ancient nation. The mysteries of Chinese ancient society documented in the texts of Travels of Marco Polo further strengthened their curiosity. However, words were ponderous and boring that require people to imagine the pictures illustrated in the texts. After the extensive application of photographic techniques in the west world, many western photographers chose China as their destination of photography.

The feature of photography determines its irreplaceable role in the preservation of folklore. It is through the use of a rich variety of pictures that it records folklore, all states of life, thereby adding a colorful chapter in the preservation and development of national culture. The over-a-century development of Chinese folk photography has witnessed western photographers to create a large number of corresponding works. The accumulation of these photographs have become a goldmine of Chinese folk cultures that offer reliable realism and visibility. There have been a host of outstanding folklore photographic works that have recorded in detail people's living conditions and their customs and activities. They have considerable folklore and philological value (Qu, 2009).

\subsection{Propagating Chinese Culture}

To some degree, folklore can be regarded as a resource, both culturally and economically. The development of folk resources can take many forms, for example photography which has become an indispensable means in folk resources development thanks to its convenience and ease of operation (Tao, 2012). Folklore photography plays a huge role in the communication of national culture. A lot of folklore is initially communicated through photographs and they are known by people as cultural phenomena. Folklore photography also connects Chinese folklore to the world. It is through the links of photography and economy that folklore receives more publicity. The news media, newspapers and magazines provide platforms for photographers to publicize folklore. Folklore photographs feature in many Chinese and international travel publications, such as Dragon-boat racing, Water-Sprinkling Festival, etc. of which media pictures have been well received in the international community, and which constitute great contributions to the dissemination of Chinese culture (Yang, 2014).

Folklore photography is a universal language shared by people of all races, religions, nations and cultural backgrounds. It facilitates communication, exchange and understanding among different nations, regions and cultures. In today's context of global integration, China must understand the world, and vice versa. In this regard photography can be used as a convenient tool to introduce Chinese folklore to the world. Photography events including HPA have effectively accelerated the cross-border exchange and integration of folklore cultures, and promoted the sharing of the world's outstanding folklore photographic works. At the same time, cross-border communication of folklore photography reflects the characteristics of photography activities in different countries and regions, facilitates the communication of folklore photography between different countries, and thereby realizes resource integration and cultural exchange.

\subsection{Broadening the Scope of Photographic Arts}

The spiritual and cultural pursuits of human beings have been enriched due to the occurrence of photographic arts. Digital technologies have penetrated into every segment of our lives along with the social development, economic leaps and arrival of information age. People can perceive the direct experience through the intuitive pictures of photographic arts without being limited by languages, nations, countries, etc. But production of excellent works seems still a difficult matter. Photographs are easy to be repetitive (Mao, 2016). Given different economic conditions and cultural backgrounds, 56 ethnic groups of china have developed their unique national psychology, customs, values, religious beliefs, moral customs, lifestyles and codes of conduct. This unique nature of folklore resources determines the richness and diversity of photography themes.

Folklore photography has both broadened the content and enriched the category of photography (Fan, 2010). It isn't equal to documentary photography that records the folklore of ethnic groups using a documentary approach. It's also different from photojournalism. It doesn't entirely fall into the category of art photography since folklore photography doesn't have to focus on light and shadow effects, shooting skills, etc. Rather, folklore photography should be taken as a kind of academic photography in view of the considerable sociological value contained in its cultural connotations and manifestations, so it is worthy of in-depth academic research (Wu, 2016).

\section{Conclusion}

Modern society is paying increasing attention to the folk photography and attaching greater importance to its value. As a multiracial civilization enjoying a profound history, China possesses rich local colors and folk connotations that are attractive to multiple western photographers. Western photographers have contributed a large amount of prominent photographs and fantastic pictures surrounding the topic of Chinese folk customs during over a hundred years since 19th century. These photographic works play an important role in the 
exploration and communication of Chinese folk cultures. In addition to the communication, they further promote the development of Chinese photography, displaying the charm of China by cameras.

\section{Acknowledgements}

This research is supported in part by the Humanities and Social Science Research Program Fund of the Ministry of Education of China (13YJC760120) and the Philosophy and Social Science Foundation of Jiangsu (2012SJB760026)

\section{References}

Sun, Y. Y. (2014). A probe into the connotation of folk photography. Art Education (Vol.35, pp. 198-199).

Tao, S.Y. (2012). Discussion on the essential factors of folk art heritage. National Arts (Vol. 2, pp. 91-95). http://dx.doi.org/10.16564/j.cnki.1003-2568.2012.02.005

Tan, Q. Q. (2004). Investigation and research on folklore photography. Journal of China West Normal University(Philosophy \& Social Sciences) (Vol. 5, pp. 94-96). http://dx.doi.org/10.16246/ j.cnki.51-1674/c.2004.05.025

Qi, T. P. (2005). Aesthetic cultural significance and expression methods of folklore photography. Journal of Chizhou University (Vol.2, pp. 55-56). http://dx.doi.org/10.13420/j.cnki.jczu.2005.02.017

Gen, X.Y. (2011). The creation of folk custom photography. Guang Zhou: Ling Nan Art Fine Press.

Zhou, T. (2016).Photography inspection on the China Shu culture and folklore of Luther. Art Science and Technology (Vol. 1, pp. 37-38).

Yang, F. \& Hu, B. B. (2015). From scientific tools to subjective emotion - ontology exploration of folklore photography. Art Observation (Vol.10, pp. 109-113).

Yang, Q. P. (2014). Analysing the image value of folklore photography through the winning works of "Human Contribution Award". Journal of Yunnan Normal University.

Jiang, B. Z. (2008). Folk photography in the view of non-material culture protection. Photographer in China(Vol.32, pp. 10-11).

Qu, L. (2009). Discussion on the cultural value and manifestation of folklore photography. Journal of Northwest University(Philosophy and Social Sciences Edition (Vol. 6, pp. 203-206). http://dx.doi.org/10.16152/j.cnki.xdxbsk.2009.06.022

Mao, Y. Q. (2016). The dilemma and way out of folk photography. Popular literature and Art (Vol.11, pp. 167-169).

Fan, Z. (2010). Folklore, photography and photographer - on the relationship among the three in the concept of folklore photography. Journal of Nanjing Arts Institute(Fine Arts \& Design) (Vol. 2, pp. 153-155).

Wu, P. K. (2016). Exploration and practice of folklore photography course teaching. Drama House (Vol.11, pp. 234-236).

\section{Copyrights}

Copyright for this article is retained by the author(s), with first publication rights granted to the journal.

This is an open-access article distributed under the terms and conditions of the Creative Commons Attribution license (http://creativecommons.org/licenses/by/4.0/). 